\title{
Quinolone Alkaloids from Evodiae fructus Inhibit LFA-1/ICAM-1-mediated Cell Adhesion
}

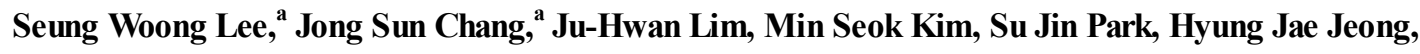 \\ Min-Soo Kim, Woo Song Lee, and Mun-Chual Rho*
}

\author{
Korea Research Institute of Bioscience and Biotechnology, Jeongeup 580-185, Korea \\ ${ }^{*}$ E-mail: wslee@kribb.re.kr(WSL); rho-m@kribb.re.kr(MR) \\ Received August 25, 2009, Accepted November 9, 2009
}

\begin{abstract}
Four quinolone alkaloids were isolated by bioactivity-guided fractionation from the methanol extracts of Evodiae fructus fruits. Structures of compounds were elucidated by spectroscopic analysis ( ${ }^{1} \mathrm{H}-,{ }^{13} \mathrm{C}-\mathrm{NMR}$ and MS), as follows: 1-methyl-2-undecyl-4(1H)-quinolone (1), evocarpine (2), dihydroevocarpine (3) and mixture of [1-methyl-2-[(Z)-10pentadecenyl]-4(1H)-quinolone and 1-methyl-2-[(Z)-6-pentadecenyl]-4(1H)-quinolone] $(4)$. They inhibited the interaction of sICAM-1 and LFA-1 in THP-1 cells at $\mathrm{IC}_{50}$ values of $>150(\mathbf{1}), 109.8(\mathbf{2}),>150(\mathbf{3})$ and $40.9 \mu \mathrm{M}(\mathbf{4})$, respectively,
\end{abstract}

Key Words: Evodiae fructus, Rutaceae, Quinolone alkaloid, Cell adhesion molecules, THP-1 cells

\section{Introduction}

Cell adhesion molecules are key mediators of inflammatory processes. In the initial adhesion events, leukocytes and monocytes are captured out of vascular flow by the selectins (E-, Pand L-) and adhered to the vascular wall by interaction of immunoglobulins and integrins such as leukocyte function-associated antigen-1 (LFA-1)/intercellular adhesion molecule (ICAM)-1, very late antigen-4 (VLA-4)/vascular cellular adhesion molecule (VCAM)-1. ${ }^{1,2}$ The interactions of integrins (LFA-1, VLA4) and ligands (ICAM-1, VCAM-1) are also important in leukocyte spreading and migration across vascular endothelium into tissue. ${ }^{3}$

LFA-1 is expressed on membranes of various cells, such as monocytes, leukocytes, and macrophages, and participated in the adhesion of these cells into the sites of inflammation. LFA-1 is a heterodimeric glycoprotein of alpha and beta chain (CD11a and CD18b), and belongs to the $\beta 2$ integrin family. ${ }^{4,5}$ ICAM- 1 , which is a member of the immunoglobulin superfamily and major ligand for LFA-1, also importantly acts in the progress of inflammation and T-cell mediated host defense systems. ${ }^{6,7}$ There is reported that the interaction of LFA- 1 and ICAM- 1 is important in the progression of the inflammatory disease such as rheumatoid arthritis, stroke, psoriasis, allergy, atherosclerosis and others. ${ }^{8-10}$ In vivo studies using anti-LFA-1 antibodies, LFA-1 plays a central role in leukocyte extravasation in recruitment model. ${ }^{11}$ And efalizumab,${ }^{12}$ the humanized anti-LFA-1 antibody, was approved for the treatment of moderate in psoriasis. Besides, many small molecule inhibitors such as antagonists mimicking the ICAM-1 ligand-binding site and targeting LFA-1 I domain have been developed and applied for several preclinical studies. ${ }^{13}$ Therefore, inhibitors of LFA-1/ICAM-1 interaction could be used as novel therapeutic agents for the treatment of inflammatory diseases.

In our search for cell adhesion inhibitors from natural sources, the methanol extracts of Evodiae fructus showed inhibitory acti-

${ }^{a}$ Both authors contributed equally to this work. vity on cell adhesion assay. This plant belong to the family of Rutaceae, the fruits have been used for treatment of gastrointestinal disorders, headache, analegic, antiemetic and amenorrhea in Korea. ${ }^{14}$ It was also reported a variety of alkaloids, terpens, and limonoids as major constituents of the fruits of this plant. ${ }^{15-18}$ In this paper, we report the procedures of isolation and structural elucidation of compounds 1, 2, $\mathbf{3}$ and $\mathbf{4}$ from Evodiae fructus and describe the inhibitory activity of the compounds on cell adhesion.

\section{Experimental Section}

General Experimental Procedures. ${ }^{1} \mathrm{H}-\mathrm{NMR}(300 \mathrm{MHz})$ and ${ }^{13} \mathrm{C}-\mathrm{NMR}(75 \mathrm{MHz})$ spectra were obtained on a Varian Unity 300 , with $\mathrm{CDCl}_{3}$ as a solvent. EI-MS was determined using a micromass autospec mass spectrometer. The HPLC system consisted of a Shimaduz Model LC-6AD pump, SPD-10A detector and YMC J'sphere ODS H- 80 column $(5 \mu \mathrm{m}, \phi 20 \times 250 \mathrm{~mm}$, YMC Co. LTD.). Reversed-phase column chromatography was conducted using RP- $\mathrm{C}_{18}$ silica gel (YMC * GEL ODS-A, $12 \mathrm{~nm}$ S-150 $\mu \mathrm{m}$, YMC Co. LTD.), and silica gel CC was conducted using Kieselgel 60 (70 - 230 and 200 - 400 mesh, Merck). TLC was conducted using Kieselgel $60 \mathrm{~F}_{254}$ plates (Merck).

Extraction and Isolation. Evodiae fructus fruits were purchased at an herbal market in Daejeon, Korea. The authenticity of the plants was confirmed by Prof. K. H. Bae, at the College of Pharmacy of Chungnam National University, Korea. A voucher specimen (PBC-272A) was deposited in the Korea Plant Extract Bank, at the Korea Research Institute of Bioscience and Biotechnology. Evodiae fructus seeds $(1.2 \mathrm{~kg}$ ) were extracted with methanol $(2 \mathrm{~L})$ for 7 days at room temperature. The methanol extract was evaporated in vacuo, yielding a residue $(210 \mathrm{~g})$. The residue was suspended in distilled water $(1 \mathrm{~L})$ and extracted with EtOAc $(1.2 \mathrm{~L})$. EtOAc-soluble was then evaporated in vacuo, with resulting extract $(57 \mathrm{~g})$ subjected to silica gel $(230$ - 400 mesh, $500 \mathrm{~g}$, Merck) column chromatography using a gradient of $\mathrm{CH}_{2} \mathrm{Cl}_{2}-\mathrm{MeOH}(100: 0 \sim 1: 1$; each $2 \mathrm{~L}, \mathrm{v} / \mathrm{v})$ as eluant to yield 
10 fractions (F1 10) by TLC profile. Each of fractions was tested for cell adhesion inhibitory activity. F3 (6 g) was subjected to silica gel $(60 \mathrm{~g})$ column chromatography using a gradient of hexane-EtOAc (5:1 1:6; each $500 \mathrm{~mL}, \mathrm{v} / \mathrm{v})$ as eluant to yield 10 fractions (F3-1 10) by TLC profile. F3-6 (737 mg) was subjected to reverse-phase column chromatography $(100 \mathrm{~g})$ eluted with $\mathrm{CH}_{3} \mathrm{CN}-\mathrm{H}_{2} \mathrm{O}(70: 1,80: 1,90: 1,100: 0$; each $500 \mathrm{~mL}$, v/v), to yield 10 subfractions (F3-6-1 10) through the based on the TLC profile. F3-6-8 (112 mg) was successively separated by semi-preparative HPLC (YMC-pack ODS-H80, flow rate $5 \mathrm{~mL} /$ min) eluted with $\mathrm{MeOH}-\mathrm{H}_{2} \mathrm{O}(85: 15, \mathrm{v} / \mathrm{v})$, yielding compounds 1 $\left(5 \mathrm{mg}, \mathrm{t}_{\mathrm{R}} 34 \mathrm{~min}\right)$ and 2 (32 mg, $\left.\mathrm{t}_{\mathrm{R}} 42 \mathrm{~min}\right)$. F3-7 (1.4 g) was subjected to reverse-phase column chromatography (100 g) eluted with $\mathrm{CH}_{3} \mathrm{CN}-\mathrm{H}_{2} \mathrm{O}(60: 1,70: 1,80: 1,90: 1,100: 0$; each 500 $\mathrm{mL}, \mathrm{v} / \mathrm{v})$, to yield 10 subfractions (F3-7-1 10) through the based on the TLC profile. F3-7-8 (600 mg) was subjected to by semiprep HPLC $\left(\mathrm{MeOH}-\mathrm{H}_{2} \mathrm{O}=90: 10, \mathrm{v} / \mathrm{v}\right)$ to yield compounds 3 $\left(97.4 \mathrm{mg}, \mathrm{t}_{\mathrm{R}} 28 \mathrm{~min}\right)$ and $4\left(25.3 \mathrm{mg}, \mathrm{t}_{\mathrm{R}} 32 \mathrm{~min}\right)$.

1-Methyl-2-undecyl-4(1H)-quinolone (1): Colorless powder. $\mathrm{C}_{21} \mathrm{H}_{31}$ NO. EI-MS m/z 313 [M] ${ }^{+}$. ${ }^{1} \mathrm{H}-\mathrm{NMR}\left(300 \mathrm{MHz}, \mathrm{CDCl}_{3}\right.$ ) $\delta 8.45(1 \mathrm{H}, \mathrm{dd}, J=6.0,2.1 \mathrm{~Hz}, 5-\mathrm{H}), 7.37-7.66(3 \mathrm{H}, \mathrm{m}, 6-, 7-$, 8-H), 6.24 (1H, s, H-3), $3.74\left(3 \mathrm{H}, \mathrm{s}, \mathrm{N}-\mathrm{CH}_{3}\right), 2.72(2 \mathrm{H}, \mathrm{t}, J=7.5$ Hz, H-1'), 1.69 (2H, m, H-2'), 1.43 (2H, m, H-3'), $1.26(14 \mathrm{H}, \mathrm{m}$, H-4' 10'), $0.88\left(3 \mathrm{H}, \mathrm{t}, J=7.1 \mathrm{~Hz}, \mathrm{H}-11^{\prime}\right) .{ }^{13} \mathrm{C}-\mathrm{NMR}(75 \mathrm{MHz}$, $\left.\mathrm{CDCl}_{3}\right) \delta 177.9(\mathrm{C}-4), 154.7(\mathrm{C}-2), 142.0(\mathrm{C}-8 \mathrm{a}), 132.0(\mathrm{C}-7)$, 126.7 (C-5), 123.3 (C-6), 115.3 (C-8), 111.2 (C-3), 34.8 (C-1'), $34.1\left(\mathrm{~N}^{\left.-\mathrm{CH}_{3}\right)}, 31.9\left(\mathrm{C}-9^{\prime}\right), 29.6\left(\mathrm{C}-7^{\prime}, 8^{\prime}\right), 29.5\left(\mathrm{C}-6{ }^{\prime}\right), 29.3\right.$ (C-4', 5'), 29.3 (C-3'), 28.6 (C-2'), 22.7 (C-10'), 14.1 (C-11').

Evocarpine (2): Colorless oil. $\mathrm{C}_{23} \mathrm{H}_{33} \mathrm{NO}$. EI-MS $\mathrm{m} / z 339$ $[\mathrm{M}]^{+} .{ }^{1} \mathrm{H}-\mathrm{NMR}\left(300 \mathrm{MHz}, \mathrm{CDCl}_{3}\right) \delta 8.44(1 \mathrm{H}, \mathrm{dd}, J=8.1,1.5$ $\mathrm{Hz}, 5-\mathrm{H}), 7.3-7.7$ (3H, m, 6-, 7-, 8-H), 6.23 (1H, s, H-3), 5.34 $\left(2 \mathrm{H}, \mathrm{m}, \mathrm{H}-8^{\prime},-9^{\prime}\right), 3.73\left(3 \mathrm{H}, \mathrm{s}, \mathrm{N}-\mathrm{CH}_{3}\right), 2.71(2 \mathrm{H}, \mathrm{t}, J=7.7 \mathrm{~Hz}$, H-1'), 2.01 (4H, m, H-7', -10'), $1.68\left(2 \mathrm{H}, \mathrm{m}, \mathrm{H}-2^{\prime}\right), 1.44(2 \mathrm{H}, \mathrm{m}$, H-3'), 1.32 (10H, m, H-4' 10'), 0.89 (3H, br t, $\left.J=6.3 \mathrm{~Hz}, \mathrm{H}-133^{\prime}\right)$. ${ }^{13} \mathrm{C}-\mathrm{NMR}\left(75 \mathrm{MHz}, \mathrm{CDCl}_{3}\right) \delta 177.8(\mathrm{C}-4), 154.6(\mathrm{C}-2), 142.0$ (C-8a), 132.0 (C-7), 130.0 (C-9'), 129.6 (C-8'), 126.7 (C-5), 123.3 (C-6), 115.3 (C-8), $111.2(\mathrm{C}-3), 34.8\left(\mathrm{C}-1^{\prime}\right), 34.1\left(\mathrm{~N}^{-} \mathrm{CH}_{3}\right)$, 32.0 (C-11'), 29.6 (C-6'), 29.2 (C-5'), 29.2 (C-4'), 29.1 ( $\left.\overline{\mathrm{C}}-3^{\prime}\right)$, 28.5 (C-2'), 27.1 (C-10'), 26.9 (C-7'), 22.3 (C-12'), 14.0 (C-13').

Dihydroevocarpine (3): Colorless powder. $\mathrm{C}_{23} \mathrm{H}_{35} \mathrm{NO}$. EI-MS $m / z 341[\mathrm{M}]^{+} .{ }^{1} \mathrm{H}-\mathrm{NMR}\left(300 \mathrm{MHz}, \mathrm{CDCl}_{3}\right) \delta 8.45(1 \mathrm{H}, \mathrm{dd}, J=$ 8.1, 1.5 Hz, 5-H), 7.35-7.69 (3H, m, 6-, 7-, 8-H), 6.25 (1H, s, H-3), $3.74\left(3 \mathrm{H}, \mathrm{s}, \mathrm{N}-\mathrm{CH}_{3}\right), 2.72(2 \mathrm{H}$, br t, $J=7.8 \mathrm{~Hz}, \mathrm{H}-1$ '), 1.68 $\left(2 \mathrm{H}, \mathrm{m}, \mathrm{H}-2^{\prime}\right), 1.26-1 . \overline{46}\left(20 \mathrm{H}, \mathrm{m}, \mathrm{H}-2^{\prime} \sim 10^{\prime}\right), 0.88$ (3H, br t, $J=$ $\left.6.6 \mathrm{~Hz}, \mathrm{H}-13^{\prime}\right) .{ }^{13} \mathrm{C}-\mathrm{NMR}\left(75 \mathrm{MHz}, \mathrm{CDCl}_{3}\right) \delta 178.1(\mathrm{C}-4)$, 154.7 (C-2), 142.0 (C-8a), 132.0 (C-7), 126.7 (C-5), 123.3 (C-6), $115.3(\mathrm{C}-8), 111.2(\mathrm{C}-3), 34.8\left(\mathrm{C}-1^{\prime}\right), 34.1\left(\mathrm{~N}-\mathrm{CH}_{3}\right), 31.9(\mathrm{C}-$ 11'), 29.6 (C-7', 8', 9', 10'), 29.5 (C-6'), 29.3 (C-3', 4', 5'), 28.6 (C- 2'), 22.8 (C-12'), 14.1 (C-13').

1-Methyl-2- $[(Z)-10$-pentadecenyl $]-4(1 H)$-quinolone and 1methyl-2-[(Z)-6-pentadecenyl]-4(1H)-quinolone (4): Colorless oil. $\mathrm{C}_{25} \mathrm{H}_{37} \mathrm{NO}$. EI-MS m/z 367 [M] ${ }^{+}$. ${ }^{1} \mathrm{H}-\mathrm{NMR}(300 \mathrm{MHz}, \mathrm{CD}-$ $\left.\mathrm{Cl}_{3}\right) \delta 8.44(1 \mathrm{H}, \mathrm{dd}, J=8.1,1.5 \mathrm{~Hz}, 5-\mathrm{H}), 7.34-7.69(3 \mathrm{H}, \mathrm{m}, 6-$, 7-, 8-H), 6.24 (1H, s, H-3), 5.34 (2H, m, H-10', -11' or H-6', -7'), $3.74\left(3 \mathrm{H}, \mathrm{s}, \mathrm{N}-\mathrm{CH}_{3}\right), 2.71\left(2 \mathrm{H}, \mathrm{br} \mathrm{t}, J=7.7 \mathrm{~Hz}, \mathrm{H}-1^{\prime}\right), 2.01(4 \mathrm{H}$, m, H-7', -10'), $1 . \overline{67}\left(2 \mathrm{H}, \mathrm{m}, \mathrm{H}-2^{\prime}\right), 1.43\left(2 \mathrm{H}, \mathrm{m}, \mathrm{H}-3^{\prime}\right), 1.32(13 \mathrm{H}$, m, H-4' 14'), 0.89 (3H, m, H-15'). ${ }^{13} \mathrm{C}-\mathrm{NMR}\left(75 \mathrm{MHz}, \mathrm{CDCl}_{3}\right)$ $\delta 177.9(\mathrm{C}-4), 154.7$ (C-2), 142.0 (C-8a), 132.0 (C-7), 130.5 (C-
11'), 129.9 (C-10'), 129.7 (C-7'), 129.1( C-6'), 126.7 (C-5), 123.3 (C-6), 115.3 (C-8), $111.2(\mathrm{C}-3), 34.8\left(\mathrm{C}-1^{\prime}\right), 34.1\left(\mathrm{~N}^{\left.-\mathrm{CH}_{3}\right)}, 32.0\right.$ (C-13'), 29.7 (C-8'), 29.4 (C-6', 7' or C-10', 11'), 29.2 (C-4', 5'), 28.9 (C-3'), 28.6 (C-2'), 27.2 (C-12'), 27.0 (C-9'), 22.7 and 22.3 (C-14'), 14.0 and 13.9 (C-15').

Adhesion of THP-1 Cells on Immobilized sICAM-1. The human acute monocytic leukemia THP-1 cells were obtained from the American Type Culture Collection (ATCC, Manassas, VA, USA). The cells were grown in RPMI-1640 medium supplemented with $10 \%$ fetal bovine serum (FBS), and incubated at $37{ }^{\circ} \mathrm{C}, 5 \% \mathrm{CO}_{2}$ in humidified atmosphere.

An adhesion assay using soluble ICAM-1 and THP-1 cells was performed as described ${ }^{19}$ with slight modifications. 96-well plates were coated with $100 \mu \mathrm{L}$ of recombinant ICAM-1 (R\&D systems) at a concentration of $5 \mu \mathrm{g} / \mathrm{mL}$ in PBS for overnight at $4{ }^{\circ} \mathrm{C}$. The wells were then washed twice with PBS and blocked with $200 \mu \mathrm{L}$ of PBS ( $5 \%$ BSA) by incubation for $1 \mathrm{hr}$ at room temperature. For fluorescent labeling of THP-1 cells, a human monocytic leukemia cell line expressing LFA-1 on its surface, $1 \times 10^{6}$ cells were washed once with RPMI 1640 were resuspended in $12 \mathrm{~mL}$ of RPMI 1640 containing $2 \mu \mathrm{M}$ BCECF-AM (Sigma) and incubated at $37^{\circ} \mathrm{C}$ for $60 \mathrm{~min}$, and washed once with RPMI 1640/1\% fetal bovine serum. Fluorescent-labeled THP- 1 cells were stimulated with LFA- $1 / 2 \mathrm{mAb}^{20}$ for $20 \mathrm{~min}$ at $37^{\circ} \mathrm{C}$. Then, THP- 1 cells and $5 \mu \mathrm{L}$ compounds were added to the wells. The plates were incubated for $45 \mathrm{~min}$ at $37^{\circ} \mathrm{C}$ and the wells were washed gently once with RPMI 1640/1\% fetal bovine serum. Fluorescent intensity was measured in a fluorescent microplate reader (FLx $800^{\mathrm{TM}}$, BioTek ${ }^{\circledR}$ Instruments, Inc., USA) with an excitation wavelength at $485 \mathrm{~nm}$ and an emission wavelength at $530 \mathrm{~nm}$.

Adhesion of THP-1 Cells on Immobilized SVCAM-1 and Eselectin. 96-well plates were coated with $100 \mu \mathrm{L}$ of recombinant VCAM-1 and E-selectin (R\&D systems) at a concentration of $5 \mu \mathrm{g} / \mathrm{mL}$ in PBS for $3 \sim 4 \mathrm{hr}$ at $37^{\circ} \mathrm{C}$. Fluorescence-labeled THP1 cells and test compounds $1-4$ (final concentration of $50 \mu \mathrm{g} / \mathrm{mL}$ ) were added to the 96-well plates coated with SVCAM-1 and Eselectin, respectively. After incubation for $1 \mathrm{hr}$ at $37^{\circ} \mathrm{C}$, fluorescent intensity was measured in a microplate reader with an excitation wavelength at $485 \mathrm{~nm}$ and an emission wavelength at $530 \mathrm{~nm}$.

Measurement of Cell Viability. Cell viability was assessed by morphology and by reduction of the tetrazolium salt MTT by mitochondrial dehydrogenase activity as described. ${ }^{21}$ The absorbance was read at $540 \mathrm{~nm}$ by using a microplate reader (Bio-rad, USA) with a reference absorbance at $650 \mathrm{~nm}$.

Data Analysis. Each experiment was performed at least in duplicate. Results are expressed or plotted as the mean value \pm standard error (SE).

\section{Results and Discussion}

In our ongoing search for cell adhesion inhibitors obtaining from natural sources, the methanol extract of Evodiae fructus fruits showed $40 \%$ inhibitory activity at the concentration of $50 \mu \mathrm{g} / \mathrm{mL}$ on cell adhesion assay. The extract was partitioned with EtOAc, and the inhibitory activity of EtOAc-soluble materials was measured $70 \%$ and $25 \%$ at $50 \mu \mathrm{g} / \mathrm{mL}$ and $25 \mu \mathrm{g} / \mathrm{mL}$, 


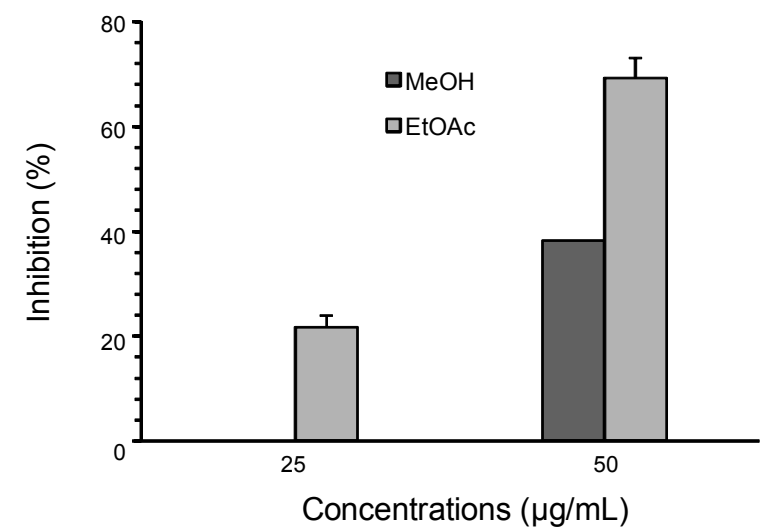

Figure 1. Effect of solvent extracts on the direct binding between sICAM- 1 and LFA- 1 of THP- 1 cells. BCECF-AM-labeled THP-1 cells and solvent extracts ( $\mathrm{MeOH}$ and EtOAc) of Evodiae fructus were added to 96-well plates were coated with sICAM-1. After incubation for $1 \mathrm{hr}$ at $37^{\circ} \mathrm{C}$, the activity was measured as described under Materials and Methods. The data are presented as the means of three independent experiments performed in duplicate.

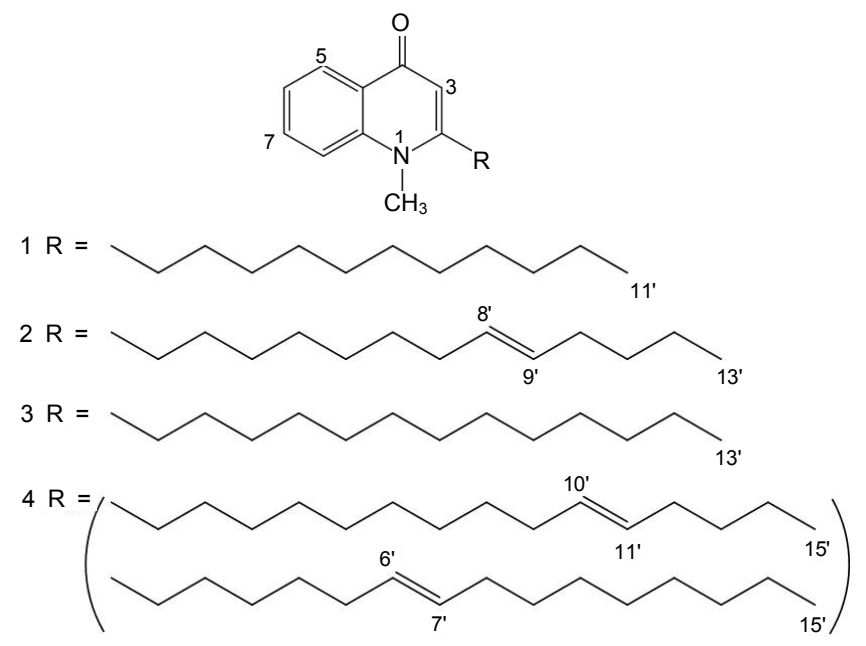

Figure 2. The chemical structures of quinolone alkaloids (1-4) isolated from Evodiae fructus fruits.

respectively (Figure 1). Therefore, the EtOAc extracts were fractionated by repeated open-column chromatography on silica gel and ODS, and subjected to semi-preparative HPLC, to yield four compounds 1, 2, 3 and $\mathbf{4}$ through in vitro cell adhesion assay test to guide isolation. The EI-MS and NMR spectra of compounds (1-4) exhibited signals due to the quinolone skeleton. These compounds showed the fragment ion peaks at $m / z 186$, 173 and 144 at EI-MS. The ${ }^{1}$ H-NMR spectrum exhibited signals due to $\mathrm{N}$-methyl group at $\delta_{\mathrm{H}} 3.73$, conjugated olefinic proton at $\delta_{\mathrm{H}} 6.22$, aromatic proton $\delta_{\mathrm{H}} 7.3-7.8$ and aromatic proton at $\delta_{\mathrm{H}}$ 8.4. In addition, the signal of olefinic protons at $\delta_{\mathrm{H}} 5.34$ was observed from that of compounds 2 and $\mathbf{4}$. As shown in Figure 2 , the structures of these compounds were identified by spectroscopic methods $\left({ }^{1} \mathrm{H}-,{ }^{13} \mathrm{C}-\mathrm{NMR}\right.$ and MS $)$ and by comparing the data obtained with those of previously reported values ${ }^{15}$ as $1-m e-$ thyl-2-undecyl-4(1H)-quinolone (1), evocarpine (2), dihydroe-
(A)

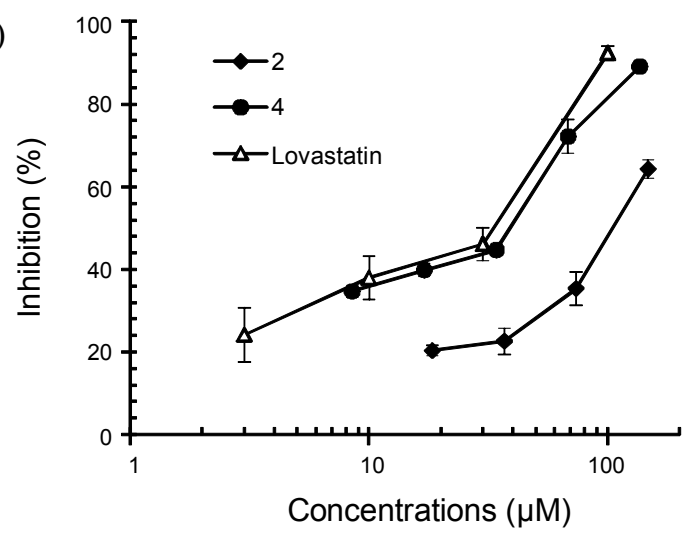

(B)
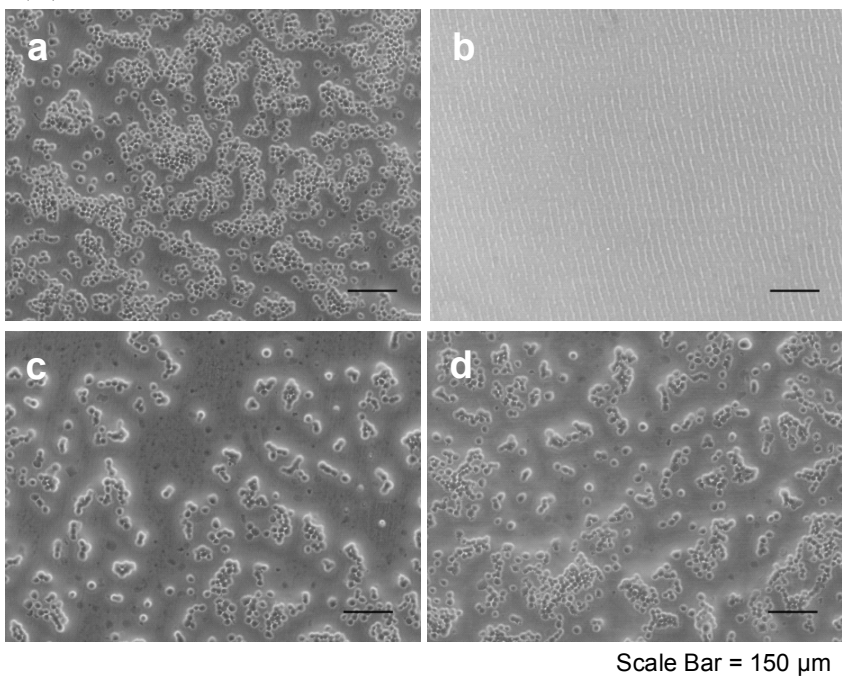

Figure 3. Inhibitory effect of compounds 2 and $\mathbf{4}$ between sICAM-1 and THP-1 cells. (A) BCECF-AM-labeled THP-1 cells and test compounds ( 2 and $\mathbf{4})$ were added to 96 -well plates were coated with sICAM-1. After incubation for $1 \mathrm{hr}$ at $37^{\circ} \mathrm{C}$, cells was dissolved with $1 \%$ Triton X-100 in PBS, and fluorescent intensity was measured in a multi-detection microplate reader at an excitation of $485 \mathrm{~nm}$ and an emission of $530 \mathrm{~nm}$. The data are presented as the means of three independent experiments performed in duplicate. The lovastatin was used as a positive control. (B) The attachment of THP-1 cells was observed by a microscope (Nikon eclipse TS100). Total magnification is $\times 100$. a: cells added to well coated with sICAM-1, b: cells added to well nocoated with sICAM-1, c: cells and compound $4(60 \mu \mathrm{M})$ added to well coated with sICAM-1, d: cells and compound $4(30 \mu \mathrm{M})$ added to well coated with SICAM-1.

vocarpine (3) and a mixture of 1-methyl-2-[(Z)-10-pentadecenyl]-4(1H)-quinolone and 1-methyl-2-[(Z)-6-pentadecenyl]4(1H)-quinolone (4) (Figure 2). And then compounds 1 and 3 have long saturated hydrocarbon chains and compounds $\mathbf{2}$ and 4 have unsaturated chains at the $\mathrm{C}-2$ position.

We tested the effect of compounds 1, 2, 3 and $\mathbf{4}$ on the direct binding between LFA-1 of THP-1 cells and recombinant sICAM-1 (R\&D systems) using modified ELISA method. ${ }^{19}$ LFA-1 is low affinity state on THP-1 cells, but it can be converted to high affinity state by LFA- $1 / 2 \mathrm{mAb}$ and other stimulus. ${ }^{20}$ Therefore, we preferentially stimulated THP-1 cells with $500 \mathrm{ng} / \mathrm{mL}$ of LFA-1/2 mAb for $20 \mathrm{~min}$, and cell adhesion inhibitory acti- 


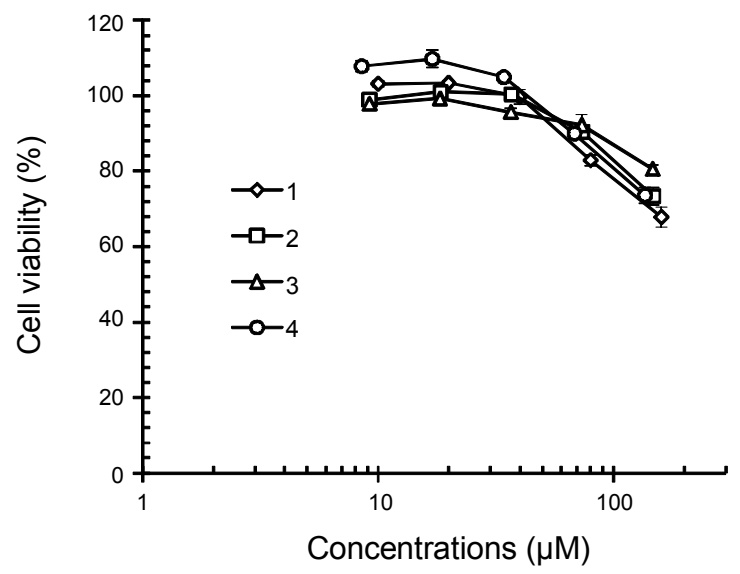

Figure 4. Effect of compounds 1- 4 on THP-1 cell viability. Cells were incubated with the indicated concentrations of the compounds 1-4 for $48 \mathrm{hr}$. The viability was determined by the MTT-based cytotoxicity assay. The \% viability was calculated as follows: (absorbance for compound treated cells / absorbance for untraeted cells $\times 100$. Data are presented as the mean $\pm \operatorname{SE}(n=3)$.

vity of 1, 2, 3 and 4 was tested. The activity was verified using lovastatin $^{22}$ as a positive control, which inhibited cell adhesion with an $\mathrm{IC}_{50}$ value of $33 \mu \mathrm{M}$ in our assay system. Compounds 2 and 4 inhibited the direct binding between sICAM-1 and THP-1 cells in a dose-dependent manner, with $\mathrm{IC}_{50}$ values of 109.8 $\mu \mathrm{M}$ and $40.9 \mu \mathrm{M}$ (Figure 3), respectively. However, compounds 1 and $\mathbf{3}$ had $25.6 \pm 5.3 \%$ and $45.8 \pm 4.9 \%$ of inhibitory activity at $150 \mu \mathrm{M}$, respectively. Because cytotoxicity can influence the inhibitory activity, THP-1 cell viability was measured by the MTT-based assay. ${ }^{21}$ Compounds 1-4 did not show cytotoxicity at the concentrations employed in this study (Figure 4). As shown in Figure 2 and 3, compounds $\mathbf{1}$ and $\mathbf{3}$ having long saturated hydrocarbon chains at $\mathrm{C}-2$ position were less potent in the inhibition of the direct binding between SICAM-1 and LFA- 1 of THP- 1 cells $(25.6 \pm 5.3 \%$ for 1 and $45.8 \pm 4.9 \%$ for 3 at $150 \mu \mathrm{M})$. However, compounds 2 and 4 having unsaturated chains showed potent inhibitory activity compared with compound 1 and $3(64.3 \pm 2.2 \%$ for 2 and $89.0 \pm 0.8 \%$ for 4 at 140 $\mu \mathrm{M})$. On the other hand, compound 2 has the same length of side chain but has one double bond at C-8 position compared with compound 3. In our experiment, compound $\mathbf{2}$ showed cell adhesion inhibitory activity with $\mathrm{IC}_{50}$ value of $109.8 \mu \mathrm{M}$ but compound 3 had low inhibitory effect $(45.8 \pm 4.9 \%$ at $150 \mu \mathrm{M})$. This result shows the presence of double bond could improve the cell adhesion inhibitory activity. In addition, compound $\mathbf{4}$ has ethylene unit in the length of C-2 side chain compared with compounds 2 . The inhibitory activity of compound 4 showed slightly improves potency with $\mathrm{IC}_{50}$ value of $40.9 \mu \mathrm{M}$, it indicates that the longer aliphatic side chain can confer a potent inhibitory effect on cell adhesion activity in compound with a one double bond. As a result, cell adhesion inhibitory activity of these compounds may be positively influenced by the presence of double bond and an increase in aliphatic side chain length.

The progressing of the inflammatory process could be delayed if the combination of the other adhesion molecules (selec-
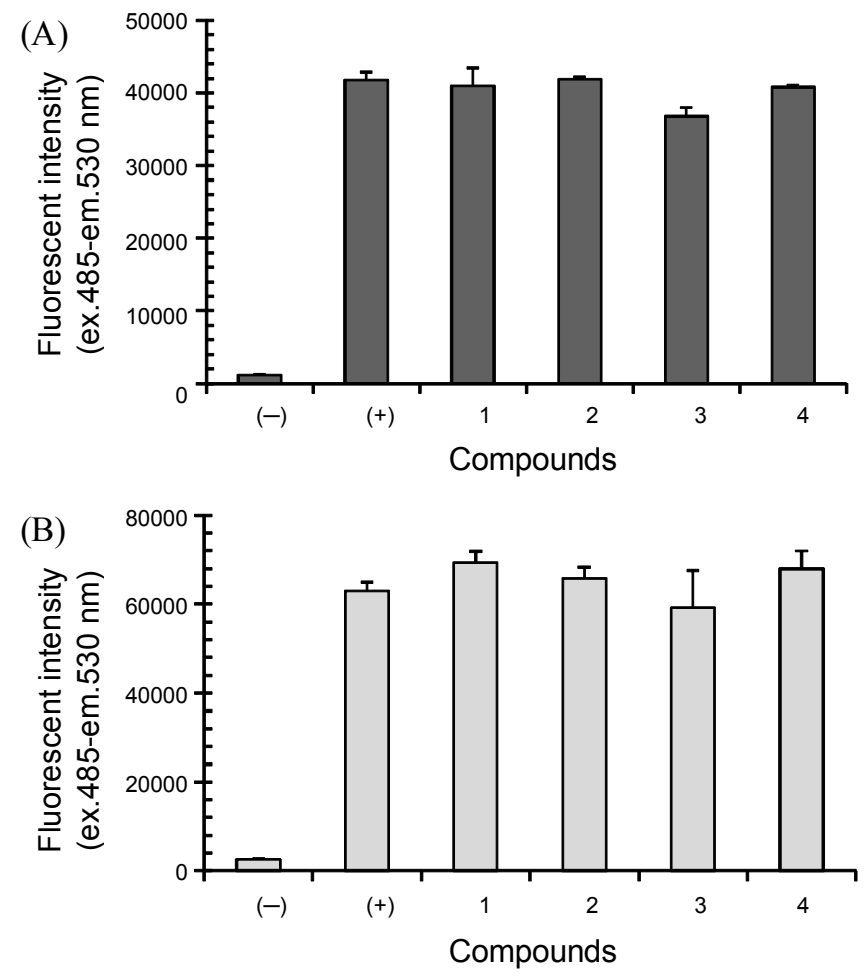

Figure 5. Inhibitory activity of compounds 1-4 on the direct binding of cell adhesion molecules (sVCAM-1 and E-selectin) and THP-1 cells. THP-1 cells and compounds 1-4 $(150 \mu \mathrm{M})$ isolated from Evodiae fructus were added to 96-well plates were coated with sVCAM-1(A) and E-selectin (B), respectively. After incubation for $1 \mathrm{hr}$ at $37^{\circ} \mathrm{C}$, cells was dissolved with $1 \%$ Triton X-100 in PBS, and fluorescent intensity was measured in a multi-detection microplate reader at an excitation of $485 \mathrm{~nm}$ and an emission of $530 \mathrm{~nm}$. The data are presented as the means of three independent experiments performed in duplicate.

tins and VCAM-1) is impeded. Therefore, we also investigated whether compounds 1-4 affect the binding between THP-1 cells and other cell adhesion molecules such as VCAM-1 and Eselectin. As a result, compounds 1-4 have no effect on direct binding assay using sVCAM-1 and E-selectin (Figure 5A and 5B). Therefore, compounds are regarded as the specific inhibitor on the binding of LFA-1 and ICAM-1.

In conclusion, four quinolone alkaloids (1-4) were isolated from the methanol extracts of the fruits of Evodiae fructus by active-guide fractionation. Recently, it was reported that quinolone alkaloids had various inhibitory activities such as leukotriene biosynthesis, ${ }^{23}$ nuclear factor of activated T cells (NFAT), ${ }^{17}$ angiotensin II receptor binding ${ }^{24}$ and diacylglycerol acyltransferase. ${ }^{25}$ But we provide new finding that these compounds have inhibitory effect on cell adhesion. These results could be useful for the design of new cell adhesion inhibitors leading to anti-inflammatory agents. Further studies on the biological activities of these compounds are now in progress.

Acknowledgments. This research was supported by a grant from the Technology Development Program for Agriculture and Forestry, Ministry of Agriculture and Forestry and KRIBB Research Initiative Program, Republic of Korea. 


\section{References}

1. Springer, T. A. Cell 1994, 76, 301.

2. Harlan, J. M.; Winn, R. K. Crit. Care. Med. 2002, 30, S214.

3. Von Andrian, U. H.; Mackay, C. R. N. Engl. J. Med. 2000, 343, 1020.

4. Springer, T. A. Nature 1990, 346, 425.

5. Hogg, N.; Henderson, R.; Leitinger, B.; McDowll, A.; Porter, J.; Stanley, P. Immunol. Rev. 2002, 186, 164.

6. Shimaoka, M.; Springer, T. A. Curr. Top. Med. Chem. 2004, 4, 1485.

7. Shimaoka, M.; Xiao, T.; Liu, J. H.; Yang, Y.; Dong, Y.; Jun, C. D.; McCormack, A.; Zhang, R.; Joachimiak, A.; Takagi, J.; Wang, J. H.; Springer, T. A. Cell 2003, 112, 99.

8. Gottlieb, A. B.; Krueger, J. G.; Wittkowski, K.; Dedrick, R.; Walicke, P. A.; Garovoy, M. Arch. Dermatol. 2002, 138, 591.

9. Ross, R. N. Engl. J. Med. 1999, 340, 115.

10. Cortran, R. S.; Mayadas-Norton, T. Pathol. Biol. 1998, 46, 164.

11. Berlin-Rufenach, C.; Otto, F.; Mathies, M.; Westermann, J.; Owen, M. J.; Hamann, A.; Hogg, N. J. Exp. Med. 1999, 189, 1467.

12. Lebwohl, M.; Tyring, K. S.; Hamilton, K. T.; Toth, D.; Glazer, S.; Tawfik, H. N.; Walicke, P.; Wang, X.; Garovoy, R. M.; Pariser, D. N. Engl. J. Med. 2003, 349, 2004.

13. Liu, G. Expert. Opin. Ther. Patents 2001, 11, 1383.

14. Jung, B. S.; Shin, M. K. Encycopedia of Illustrated Korean Natural
Drugs; Young Lim Sa: Seoul, 1990; p 786.

15. Sugimoto, T.; Miyase, T.; Kuroyanagi, M.; Ueno. A. Chem. Pharm. Bull. 1988, 36, 4453.

16. Rho, T. C.; Bae, E.; Kim, D.; Oh, W. K.; Kim, B. Y.; Ahn, J. S.; Lee, H. S. Biol. Pharm. Bull. 1999, 22, 1141.

17. Jin, A. Z.; Lee, J. H.; Lee, D.; Lee, H. S.; Hong, Y. S.; Kim, Y. H.; Lee, J. J. Biol. Pharm. Bull. 2004, 27, 926.

18. Han, X. H.; Hong, S. S.; Lee, D.; Lee J. J.; Lee, M. S.; Moon, D.; Han, K.; Oh, K.; Lee, M. K.; Ro, J. S.; Hwang, B. Y. Arch. Pharm. Res. 2007, 30, 397.

19. Joseph, R. W.; Daw-tsun, S.; Viviany, R. T.; Nancy, H.; Terence, A. K.; Takashi, K. K. J. Leuko. Biol. 2001, 70, 329.

20. Carman, C. V.; Jun, C. D.; Sala, A.; Springer, T. A. J. Immunol. 2003, 171, 6135 .

21. Mosmann, T. J. Immunolog. Methods 1983, 65, 55.

22. Gabriele, W. S.; Karl, W.; Volker, B.; Tetsji, K.; Joerg, K.; Christian, B.; Sylvain, C.; Yoshikazu, T.; Ulrich, H. Nature Med. 2001, $7,687$.

23. Adams, M.; Kunert, O.; Haslinger, E.; Bauer, R. Planta Med. 2004, $70,904$.

24. Lee, H. S.; Oh, W. K.; Choi, H. C.; Lee, J. W.; Kang, D. W.; Park, C. S.; Mheen, T. I.; Ahn, J. S. Phytother. Res. 1998, 12, 212.

25. Ko, J. S.; Rho, M.; Chung, M. Y.; Song, H. Y.; Kang, J. S.; Kim, K.; Lee, H. S.; Kim, Y. K. Planta Med. 2002, 68, 1131. 